\title{
INFLUÊNCIA DA EMBALAGEM NA QUALIDADE FÍSICO-QUÍMICA E ANÁLISE SENSORIAL DE AZEITES DE OLIVA EXTRAVIRGEM E ÚNICO
}

\section{Pâmela Gomes de Souza1(pgdsouza.pharma@gmail.com); Mirian Ribeiro Leite Moura1; Igor de Almeida Rodrigues1; Fábio Cerdeira Lirio2; Carla da Silva Carneiro1}

\author{
1 Faculdade de Farmácia, Universidade Federal do Rio de Janeiro (UFRJ), Brasil
}

2 Escola de Química, Universidade Federal do Rio de Janeiro (UFRJ), Brasil

O armazenamento inadequado do azeite de oliva é o principal fator responsável pela deterioração lipídica deste produto. Comumente, observa-se em bares e restaurantes, azeites sendo oferecidos para consumo armazenados em recipientes de vidro transparente e sem vedação. Sendo assim, este trabalho teve como objetivo avaliar as alterações físico-químicas do azeite de oliva extravirgem e único mantidos em dois diferentes tipos de embalagens: embalagens originais com vidro escuro e fechadas (controle) e embalagens de vidro transparente e mantidas abertas (teste). Os azeites também foram avaliados sensorialmente através de testes afetivos de aceitação e preferência por 58 avaliadores não treinados. As análises físico-químicas foram realizadas durante aproximadamente 60 dias de armazenamento. Foram utilizados métodos quantitativos para determinação do índice acidez e peróxidos. Com os resultados obtidos foi possível observar que para o azeite extravirgem mantido na embalagem teste ocorreu alteração significativa do índice de acidez entre o $44^{\circ}$ e $51^{\circ}$ dia de estocagem (aumentando de 0,40 para 0,54 g de ácido oleico/100g). Para o azeite tipo único o aumento significativo ocorreu antes, entre o $37^{\circ}$ e o $44^{\circ}$ dia (1,51 para $1,64 \mathrm{~g}$ de ácido oleico/100g). Em contrapartida, nas amostras mantidas na embalagem controle não houve alteração na acidez durante os 65 dias de armazenamento. No tocante ao índice de peróxido, nas amostras de azeite extravirgem armazenadas na embalagem teste, o aumento foi de 5,86 para $42,72 \mathrm{mEq} / \mathrm{Kg}$ entre o $1^{\circ}$ e o $37^{\circ}$ dia de armazenamento. Verificou-se que este mesmo azeite mantido na embalagem controle apresentou menor variação (de 5,86 para 12,34 mEq/Kg entre o $1^{\circ}$ e o $37^{\circ}$ dia). Com relação às amostras de azeite tipo único, quando mantidas na embalagem teste, apresentaram aumento significativo no índice de peróxidos já entre o $1^{\circ}(14,36 \mathrm{mEq} / \mathrm{Kg})$ e o $9^{\circ}$ dia $(20,78 \mathrm{mEq} / \mathrm{Kg})$, entretanto, nas amostras mantidas na embalagem controle a variação só foi significativa entre o $1^{\circ}(14,36 \mathrm{mEq} / \mathrm{Kg})$ e o $65^{\circ}$ dia de estocagem $(24,14 \mathrm{mEq} / \mathrm{Kg})$. Estes resultados evidenciam que o tipo de embalagem possui importante influência na conservação da qualidade do azeite de oliva, devendo-se evitar a transferência do produto para embalagens que permitam a ação de fatores externos responsáveis por sua deterioração. No que se refere às análises sensoriais, o azeite de oliva extravirgem recebeu maior nota para os atributos sabor e aparência global no teste afetivo de aceitação $(\mathrm{p}<0,05)$ e foi preferido no teste afetivo de preferência em comparação ao azeite tipo único.

Palavras-chave: estabilidade química; alteração da qualidade; análise sensorial. 